\title{
OF FOOD COURTS AND OTHER DEMONS: SHOPPING MALLS IN MEXICO AS NEW CENTERS FOR URBAN LIFE
}

\author{
Carolin Loysa ${ }^{1}$ \\ Sin embargo, siempre asistió obligado a los actos públicos \\ porque nunca pudo vencer el espanto de la vida social. \\ Del amor y otros demonios
}

During the World Cup 2014 one of the four most prestigious shopping malls in Mexico, the centro comercial Angelópolis in Puebla, published this promotion picture ${ }^{2}$ on its official facebook page.

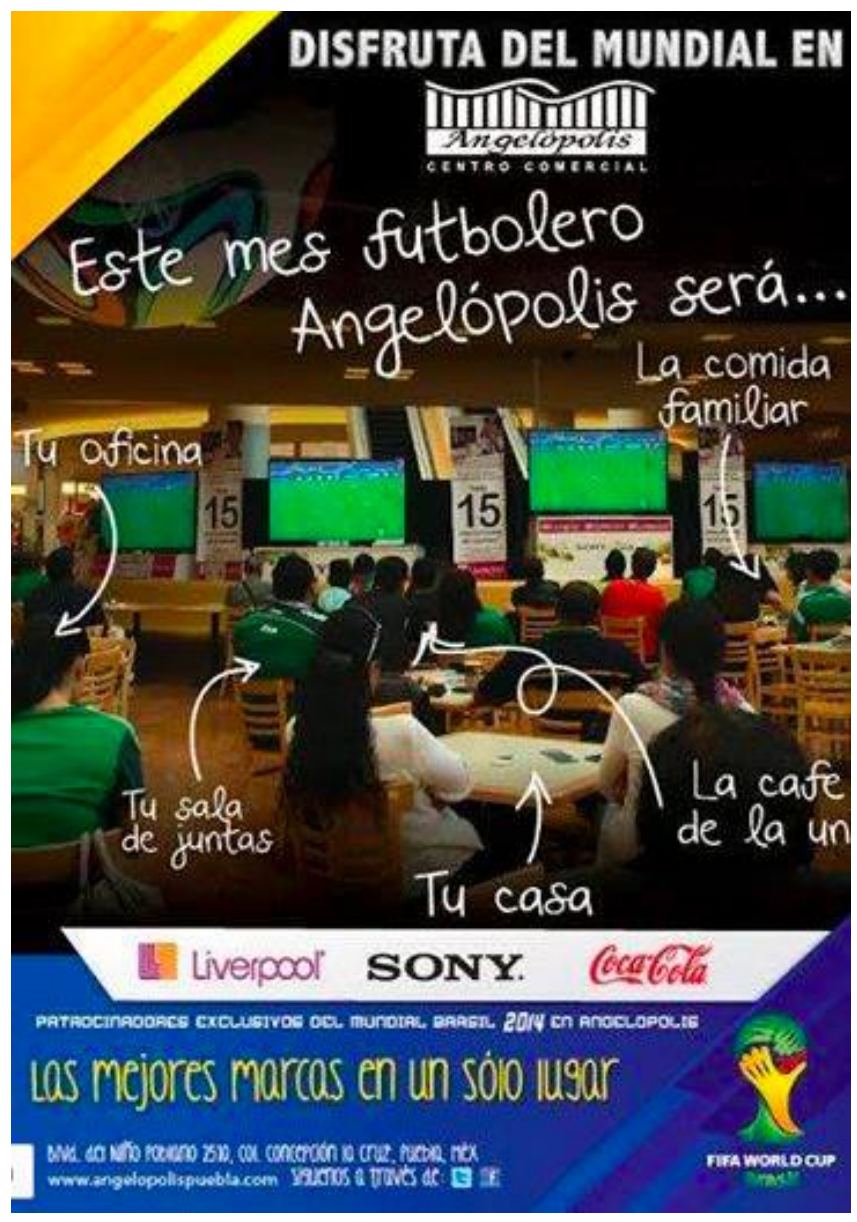

It praises the mall not only as being the perfect place for all sorts of social encounters - for example to watch the World Cup matches - but, as it seems, for all the activities of our everyday life. But what is missing here? And what makes malls, especially in Mexico, so successful and draws so many city residents in to spend their time there?

\footnotetext{
${ }^{1}$ Institute for Latin American Studies, Freie Universität Berlin, Germany.

${ }^{2}$ Source: Facebook (Site: Centro Comercial Angelopolis Puebla), June 25th, 2014.
} 
Nowadays malls are much more than only centers of consumption. In times of globalization they offer a - or even the - space for social encounter. We find malls in almost every bigger city in the world. They tend to adapt to the particular realities of the countries they are built in but altogether they are all very similar. Malls offer a space where everybody, no matter where from, knows their way around - the food court being the center of every mall worldwide.

To get an impression of what 'being in the mall' means, I would like to reconstruct a visit to one of them, the centro comercial Angelópolis in Puebla mentioned above:

Our car passes the highway and takes a turn to enter the huge parking lot. We have to pass the gate where a voice tells us that the first 15 minutes of parking are free. After driving around for five minutes we luckily find a place near the entrance of the food court, guarded by an armed policeman, where people usually meet. Going in we pass two restaurants, one belonging to a US-chain, the other belonging to a Mexican chain. At each door a waiter welcomes us to invite us in. We politely reject and finally arrive at the food court. Through the glassed ceiling the sunlight is dazzling. It is a normal workday and the food court is crowded because for most people it is lunchtime. It is loud and the voices become blurred which may be due to the fact that the whole place is built in marble. A lot of tables are pulled out of their destined position and put together to seat bigger groups of people. The security guards in their suits observe everything and sometimes, when people leave, put the tables back in their place and help the cleaners to collect the garbage people have left behind. The temperature is pleasant. It smells like food. Around the food court are several restaurants that all belong to chains, mostly fast food. From Japanese to tacos to coffee to steak or Italian or even pastries you find everything. We see a lot of groups of younger people in their school uniforms but also families, young couples or two girlfriends chatting over lunch. A lot of people seem to know each other and go by the tables to greet someone they just saw. We pass the food court and get into the area where all the shops and the department stores are. Suddenly it is empty, the noise of the food court seems farther away and is replaced by the rushing of the water in the fountain, at the center of the mall. Here only a few people stand around, looking at their cellphones, probably waiting for someone. We see conspicuously few people with shopping bags. The few we see seem in a rush. This is a contrast to Sundays where a lot of families are in the mall and stroll for hours. 
Malls are mainly the result of broad privatization measures that took place in the last decade, especially in Latin American cities. These privatization measures are officially extolled as being an improvement for the city's image. What mostly really happens is the emergence of homogenized spaces that include one group and exclude another. In consequence, what makes this phenomenon interesting for an anthropological study are the socio-spatial practices ${ }^{3}$ that go beyond the intended use of a mall. As for Puebla, it seems that the lives of the inhabitants or of certain groups of inhabitants revolve more and more around the food court.

Porque es un lugar donde pueden venir las familias a convivir. Hay lugar para todos aquí. Los que quieren ir de compras, los que quieren comer, los niños tienen un espacio para jugar. Se me hace más complete y en el mismo lugar. ${ }^{4}$

This article wants to give a brief insight on the impact that malls can have on Mexican cities, using the city of Puebla as an example. What is it that makes malls so attractive and how does this change social dynamics in the urban landscape? The question asked at the beginning - what is missing? -links to the title mentioning "other demons". ${ }^{5}$ With this are meant are the things that the emergence of malls in Latin America entails. It is no secret that privatization measures, malls being at the heart of these measures in Mexico, provoke more and more a hierarchical division of the city.

Before we get to "identify the demons", I would like to take a step back and give a short introduction of the constitution of the city of Puebla and furthermore of the particularities of Mexican cities to understand why they seem to offer an especially fertile ground for the success of malls.

Puebla, the homonymous capital of the state of Puebla, is a metropolis that, besides the famous Centro Histórico that belongs to the UNESCO world cultural heritage, harbors a multitude of malls that all comply with the classical characteristics. The city houses more than 1.5 million people ${ }^{6}$ and is one of the fastest growing cities in Mexico. It is also considered to be one of the four most important cities in Mexico - due to its history, the number of inhabitants and its important contribution to the national

\footnotetext{
${ }^{3}$ This term is linked to Bourdieu's definition of the habitus - the cultural competence of social actors to produce a multitude of diverse practices (social acts), each carrying the structural characteristics of the internalized cultural system (cf. Gutiérrez, 2012).

${ }^{4}$ Extract of an interview with a visitor (saleswoman, 58 years old) conducted in Angelópolis, April 2012).

${ }^{5}$ In this context 'demon' is not to be understood as something that is necessarily bad, but something that can, in a certain way, possess you and influence the decisions you make.

${ }^{6}$ According to the last official census in 2010.
} 
economy (cf. Rubalcava/Schteingart, 2012). It is a conurbation that, because of its size, can be referred to as a metropolis but still seems to appear to its inhabitants as a smaller city without the broad anonymity of large cities. This reflects on the discourses of the inhabitants considering the city they live in.

Puebla is known to be one of the safest cities in Mexico, meaning that the number of crimes here is still at a manageable size. Nonetheless, there exists a profoundly enshrined discourse on insecurity that has increased immensely in the last years and influences the socio-spatial practices in the city.

Since the city was founded in 1531 it has received the nickname La Ángelópolis (the city's original name being Puebla de los Ángeles). This may also be the reason why the shopping mall that opened in the suburbs of the city in 2002 was called centro comercial Angelópolis. This mall belongs to the four most prestigious malls in Mexico due to its generous design, size and especially the fact that it houses more than three department stores. The opening of the mall was the starting point for the consolidation of a new, supposedly modern and globalized area of the city. Nowadays, around the mall we find new private schools, private hospitals, supermarkets (such as Walmart) and most important residential areas, the so called fraccionamientos, that are all well protected behind walls and guarded by private security and gates. The newest of these achievements are the La Vista Towers. On the website the concept of this urban achievement is promoted with the following words:

Ubicado en una de las zonas más exclusivas de la moderna y tradicional ciudad de Puebla, La Vista Towers es más que una inversión inteligente: se trata de una innovadora concepción de los espacios para la convivencia diaria, (...)

La Vista Towers es un desarrollo residencial inédito, porque es el único inspirado desde su creación para aquellas personas que saben reinventar sus tradiciones y, al mismo tiempo, experimentan las bondades que sólo el estilo de vida más contemporáneo puede ofrecer. Es el lugar ideal para quienes buscan la tranquilidad de un rincón propio con las virtudes de los complementos más modernos, al mismo tiempo que garantizan con su inversión un futuro propicio.

Estos lujosos condominios panorámicos forman parte del exclusivo desarrollo residencial La Vista Country Club. Cuentan con un generoso espacio interior y un escenario exterior coronado por un magnífico entorno natural, ofreciendo la tecnología y la seguridad más adecuadas para hacer que cada dia sea todo un evento extraordinario de convivencia y buen gusto. ${ }^{7}$

\footnotetext{
${ }^{7}$ http://www.lavistatowers.com/towers.html (last accessed September 15th, 2014)
} 
The area around the mall provides one with everything that one could need and is not only the new center of attention, but a whole new district that seems to appear as the new center of the city. But what does 'center of the city' mean in Mexico? It is important to look at the special constitution of Mexican cities where the center of the city is a place that connects people not only with each other, but also with their culture, history, and identity.

The center and heart of every Mexican city is the plaza mayor or, in the vernacular, the Zócalo. It is and has been the central public meeting point with a tradition that goes back to pre-colonial times. Usually the Zócalo is surrounded by the most important buildings of the city, meaning the Cathedral and the Town Hall. Every manifestation or protest starts at the Zócalo. But maybe even more important is the fact that it is the place where people meet, where they spend their free time together, chat with each other on the benches or stroll around in the city center. Also in most cities it is a green spot with trees and grass and a place where children have been magically drawn to the big fountain for decades if not centuries. The Pueblan anthropologist Licona Valencia describes the Zócalo as an emblematic central space of urban life with a symbolic charge that makes it the most important place in the city. (cf. Licona Valencia, 2007a: 14).

Taking this fact into consideration makes it clear that the socio-spatial practices concerning the mall in a Mexican city need to be looked at from a different angle. The beneficiary interests on the part of the inhabitants concerning malls in Mexican cities are different from other urban contexts or traditions because of the importance of public places in Mexican culture. ${ }^{8}$ Licona Valencia also states that in modern cities like Puebla, urban space is used and perceived in very diverse manners by the totality of the city's inhabitants (cf. Licona Valencia, 2007b: 33). He refers to a diversity of social classes that divide the urban space according to their needs. As to be understood through the following statement, it becomes clearer that unlike the Zócalo, malls don't seem to be for everyone even if they are perceived equally as a public space by the inhabitants.

\footnotetext{
${ }^{8}$ The 'public' is being understood as a dimension of collective life that was often connected with the state. Nowadays, the political dimension of 'the public' or public places seems to lose weight. This indicates that the idea of a dichotomy between public and private space now, more than ever, needs to be reconsidered (cf. Light/Smith, 1998; Rabotnikof, 2010).
} 
[El Zócalo] Es otro lugar distinto obviamente. Pues edificios coloniales, hay otro tipo de gente. Es más libre. Hay más gente de las diversas clases sociales. ${ }^{9}$

\section{The Demons of Globalization}

"Ni chalupas, ni quesadillas" I was told when asking about the food in the mall. I interviewed a father who was eating in the food court in Angelopolis with his family. He told me that this kind of food was not of his culture and more of the Anglo-Saxon style. He also told me that this was part of globalization - hamburgers, pizza, all this fast food.

Food in Mexico has an important status not only as moment of tradition but in the everyday life. The Mexican cuisine was appointed Intangible Cultural Heritage by the UNESCO in 2010 and is an often discussed subject through all levels of society. The food court is the new place for the weekly family meetings but what happens here is much more than just a change of place. At a first glance, one might think that due to the emergence of the malls certain traditions get lost. What actually happens is a reinvention of these traditions.

Thriving Latin American cities like Puebla are in an area of tension between extreme forms of tradition and (global) modernization. This generates the possibility "de integración internacional y a la vez desigualdad, exclusión económica y cultural" (García Canclini, 1999:168). In this context García Canclini talks about a dualization between the global and the local city that provokes a redistribution of social practices in the urban space, leading to new attractive spaces like malls (cf. García Canclini, 1999:168-171). This redistribution of social practices taking place in Puebla leads to a redistribution of places - the mall being exclusively for people of the middle and upper class ${ }^{10}$ whereas the traditional plaza, the Zócalo is more for people belonging to the middle and lower class. This on the other hand also provokes a redistribution of urban territory with two central districts: one around the Zócalo, the other one around the mall. Belonging to the globalized world seems to be a privilege for those with more economic possibilities.

\footnotetext{
${ }^{9}$ Extract of an interview with a visitor (lawyer, male, 63 years old) conducted in Angelópolis, April 2012).

${ }^{10}$ The term "class" is used after extensive fieldwork in Puebla. The inhabitants themselves use this term and assign places to social classes.
} 
"Se acude al mall a experimentar la ciudad posible, ya no la del recorrido interminable y las calles encequecedoras, sino la ciudad previsible, reiterative y carente de hechizo (...) malls resultan embajadas de globalización, clonadas porque el mensaje es único.” (Monsiváis, 2010: 342-343)

Inhabitants, in their function as social actors, use the mall as a globalized and modern space and adapt certain behavioral patterns that correspond to a way of life they strive for. Being part of the so-called 'globalized world' appears to be an important achievement and a reason to make the mall their new plaza mayor.

The Puerto Rican sociologist Dávila Santiago describes the epoch of globalization as the epoch of the "imagen del mundo" (Dávila Santiago, 2005: 16). He understands the concept of the world as an image that is neither empty nor passive but houses a configuration of rules, ideas and forms that influence people's social actions (ibid: 1617). García Canclini argues with a similar idea as he states that most of what happens in our every day life is imagined - filled with certain images and ideas - because it can't happen out of real interaction (García Canclini, 1997: 88). We make assumptions about certain things that we don't, or are not able to understand. The idea of globalization is not a static concept with a fixed definition. What we as social actors know is the fact that we live in a globalized world and have to find our way around to prevent appearing backwards.

Kearney describes the concept of globalization as a social, economic and demographic process in the nations (Kearney, 2008: 52) ${ }^{11}$. This provokes the assumption that processes of globalization are decentralized in the national territories and in the global space. Combining these considerations may lead to the idea that social actors, finding themselves in the context of globalization, are searching for a niche to withdraw to. They assume that being in this niche - the mall - enables them to feel part of the globalized, modern world. This idea obviously provokes changes in the behavioral patterns of the social actors in the city. Yet, the idea of globalization, even if certainly worth considering, implies a process of opening up. The reality of the mall does not fall in line with this: used as a niche it implies inclusion much more than opening up. Therefore, it is more of an imagined globalization, provoking mechanisms

\footnotetext{
${ }^{11}$ Not to be mistaken with the concept of transnationalization where borders are crossed over and which can be understood mainly through processes of migration.
} 
of exclusion as the appropriation of the space ${ }^{12}$ "mall" is determinedvia the economic status.

Las clases medias y altas se integran a la nueva política económica mediante un individualismo posesivo centrado en el consumo personalizado. (García Canclini, 1997: 29)

So far we have focused on the actor's perspective but these dynamics should also be embedded in a broader context. The emergence of malls, still under the guise of globalization, is also the result of the interests and changes of the market ${ }^{13}$. Investigating the subject of globalization one inevitably comes across privatization. Both terms are often being named in one breath. According to García Canclini privatization measures ${ }^{14}$ promote the subordination of Latin American cultures to the big cosmopolitan monopolies (García Canclini, 1997: 489). The market supports the "cultura-mundo" (García Canclini, 1997: 49) that leads to social homogenization (ibid.). The term homogenization, as used by García Canclini, refers to the worldwide homogenization of culture that is promoted in places like malls. At a local, urban level, this appears differently: within a society, this "cultura-mundo" leads to a heterogenization of the urban society.

\section{The Demons of Status and Fear}

So far we have established that being in the mall provides us with a certain social status because it makes us feel a part of the globalized world. Therefore we also put up with being included in this space and excluding other groups. Nevertheless, this exclusion has two main other reasons that shall be discussed here and may also explain a bit more the mall's success in Mexican cities.

\footnotetext{
${ }^{12}$ The concepts at the basis of this approach are Lefebvre's "Production of Space" and Michel de Certeau's "Practice of Everyday Life". They provide a way for understanding everyday practices in urban space - social actors appropriate space and transform it according to their needs through their ways of using this space. Lefebvre declares that "(social) space is not a thing among other things, nor a product among other products: rather it subsumes things produced, and encompasses their interrelationships in their coexistence and simultaneity - their order and/or (relative) disorder" (Lefebvre 1974: 73). Space is linked to and created through mental processes and exists on an abstract and mental level. The diverseness of social practices can be reflected in social spaces.

${ }^{13}$ Here simplified understood in the economical sense as encounter of supply and demand.

${ }^{14}$ Understood as postponements of public activities into the private sector.
} 
The promotion of the La Vista Towers quoted above has two key phrases that show the other two demons that shall be identified in this article. The first one is the phrase where the area around the La Vista Towers (and therefore also around the mall) is called "la zona más exlcusiva". Leading an exclusive lifestyle provides us with a form of social status. But being exclusive in the original sense of the word always means having to exclude others. Bourdieu defines this form of prestige or status as symbolic capital. It represents the ability to show our social status through our habitus, lifestyle and forms of social distinction. This type of recognition, however, could not be gained without economic, social or cultural capital. ${ }^{15}$ The idea of the symbolic capital, according to Bourdieu, is to make the disposal of these things audible (cf. Bourdieu, 1983).

En muchos casos la gente va para ver y verse. Para que lo vean y para ver quien está ahí. Hay un deseo neurotico de pertenencia a un estatus social y el ir a Angelópolis representa ir a codearse con el mundo globalizado y con quien tiene el poder económico. ${ }^{16}$

The mall Angelópolis constitutes a form of exclusion that may be a result of the wish to distinguish oneself from the Other, hereby meaning people that belong to another social class. The access to the globalized world in this context appears to be an exclusive commodity and depends on economic possibilities. The mall may seem as an open space where everybody is welcome but it is not. There also is already a form of exclusion in the mall, making fun of those visitors who come and spend the whole afternoon at the food court with only an ice cream bought at Mc. Donald's. Medina Cano calls consumption a symbolic power of the exclusive that cultivates social exclusion (cf. Medina Cano, 1998: 83). The differentiation of social classes manifests itself over practices of consumption. Cornejo Portugal describes the mall's own "socialidad" that is established over the social actors' strategies (in form of certain objects such as clothes etc.) and which helps them to communicate and interact (Cornejo Portugal, 2007: 134). The space mall and the social actors find themselves in a reciprocal relationship: the affiliation to the space mall constitutes the visitors' social status just as the mall's prestige is determined by the social status of the visitors.

\footnotetext{
15 Social capital means the affiliation to one particular group, precondition being material goods (economic capital) and cultural skills (cultural capital). (Bourdieu, 1983)

${ }^{16}$ Extract of an interview with the Pueblan historian Dr. Carlos López García conducted in Puebla, April 2012.
} 
But there is a second phrase out of the La Vista Towers' quote: "la seguridad más adecuada". There exist different narratives that are designed and constituted through a form of fear. This fear is supported by the media and serves as justification for new processes of exclusion (cf. Araya, 2009, Caldeira, 2000, Low, 2003).

Las élites dominates ligadas a la globalización, practican una serie de estrategias con el fin de provocar e instrumentalizar el temor en la sociedad civil, de pensar y actuar distinto a lo estipulado por ellas. (Araya, 2009: 58)

Low identifies a culture of fear where - with the help of the private governing body -certain prejudices and fear are supported and stimulated. This leads to a new spatial identity that manifests itself in places like malls (Low, 2003: 389-390). This is also reflected in the statements collected by the visitors:

\begin{abstract}
Para un café y esto prefiero aquí porque hay Valet [Parking]. O ir a un restaurant. A mí me da ya la inquitud ir a otros lados como el salón de belleza. (...) Aquí es más cerrada y hay seguridad. Ir a otros lados si me causa estrés. Bajo al salón de belleza sin reloj, sin anillos, sin nada, con mi dinero para pagar. Te sientes muy vulnerable. En cambio aquí vienes a comprar tranquila. La verdad tranquila. No digo que no te pueden asaltar pero me da más seguridad. ${ }^{17}$
\end{abstract}

In fact in the last years it has been known that in Puebla, especially in the Centro, the number of robberies has increased. In Angelópolis no such things are known, instead there have been cases of assaults and kidnapping.

Malls are closed spaces whose walls award us with the feeling of safety, which may be a reason why Low articulates a dependence of walls: "Residents are using the walls, entry gates, and guards in an effort to keep the perceived danger outside of their homes, neighborhoods, and social world.” (Low, 2003: 402)

The aspect of confrontation is being projected on different groups of social actors. Caldeira notices that people don't trust public institutions anymore and therefore create groups of people that are being naturalized as dangerous (Caldeira, 2000: 3). In consequence this means that the presence of a certain social class determines the status of safety at a place. Furthermore, safety becomes a private commodity that can be "afforded".

\footnotetext{
${ }^{17}$ Extract of an interview with a visitor (accountant, female, 58 years old) conducted in Angelópolis, April 2012.
} 
A food court and a traditional plaza pública are both limited areas with four sides. Both of them are places where people meet, chat, eat and spend their time. The Zócalo has always been the heart of Mexican cities where people gather. Now there seem to be two hearts and two central districts in cities like Puebla, assigning each social class to their envisaged urban space. Cities are always in flux and can never be fully understood or seized. City residents are social actors who use and change the urban space according to their needs, even if this means giving in to the demons (that subconsciously influence our acts) and cutting themselves off from the supposedly 'dangerous others'.

\section{References}

ARAYA, María del Carmen (2009): El miedo asecha y el consumo seduce. Dos caras del modelo psicológico dominante en tiempos de globalización. Pontificia Universidad Javeriana, Bogotá, Colombia, Universitas Humanística, núm 67, pp. 55-79.

BOURDIEU, Pierre (1983): Ökonomisches Kapital, kulturelles Kapital, soziales Kapital. In: Soziale Ungleichheiten (Soziale Welt Sonderband 2), ed. Reinhard KRECKEL, Göttingen, pp. 183-198.

CALDEIRA, Teresa P.R. (2000): City of Walls - Crime, Segregation and Citizenship in São Paulo, University of California Press, Berkeley.

CERTEAU, Michel de (1980): The practice of everyday life. University of California Press, Berkeley.

CORNEJO PORTUGAL, Inés (2007): El lugar de los encuentros. Comunicación y cultura en un centro comercial. Universidad Iberoamericana, Mexiko.

DÁVILA SANTIAGO, Ruben (2005): El Mall - Del Mundo al Paraíso. Ediciones Callejón, San Juan, Puerto Rico.

GARCÍA CANCLINI, Néstor (1997): Imaginarios Urbanos. Buenos Aires, Ed. Univ. de Buenos Aires.

GARCÍA CANCLINI, Néstor (1999): La Globalización imaginada, Ed. Paidós, Argentina.

GARCÍA MÁRQUEZ, Gabriel ([1994] 2010): Del amor y otros demonios. Debolsillo, Barcelona.

GUTIÉRREZ, Alicia B. (2012): Las prácticas sociales. Una introducción a Pierre Bourdieu. Eduvim, Argentina.

KEARNEY, Michael (2008): Lo local y lo global: la antropología de la globalización y el transnacionalismo. In: Espacios y transnacionalismo (ed. HIERNAUX, Daniel \& Margarita 
ZÁRATE), Universidad Autónoma Metropolitana - Unidad Iztapalapa, Casa Juan Pablos Centro Cultural, pp. 51-88.

LEFEBVRE, Henri ([1974] 1991): The Production of Space. Blackwell Publishing.

LICONA VALENCIA, Ernesto (2007a): Introducción. In: El zócalo de la ciudad de Puebla. Actores y apropiación del espacio. (ed. Ernesto LICONA VALENCIA) Benemérita Universidad Autónoma de Puebla, Mexico, pp. 11-18.

LICONA VALENCIA, Ernesto (2007b): Espacio y cultura: un acercamiento al espacio público. In: El zócalo de la ciudad de Puebla. Actores y apropiación del espacio. (ed. Ernesto LICONA VALENCIA) Benemérita Universidad Autónoma de Puebla, Mexico, pp. 19-44.

LIGHT, Andrew \& Jonathan M. SMITH (1998): Introduction: Geography, Philosophy, and Public Space. In: Philosophy and Geography II - The Production of Public Space (ed. LIGHT, Andrew \& SMITH, Jonathan M.), Rowman \& Littlefield Publishers, Boston, pp. 1-16.

LOW, Setha M. (2000): On the Plaza. The Politics of Public Space and Culture. University of Texas Press.

LOW, Setha M. (2003): The Edge and the Center: Gated Communities and the Discourse of Urban Fear. In: The Anthropology of Space and Place - Locating Culture (ed. Denise LAWRENCE-ZÚÑIGA \& Setha M. LOW), Blackwell Publishers, pp. 387-407.

MEDINA CANO, Federico (1998): El Centro Comercial: Una "Burbuja de Cristal". Estudios sobre las CUlturas Contemporaneas, Universidad de Colima, Mexico, año/vol. IV, núm. 008, pp. 61-91.

http://redalyc.uaemex.mx/pdf/316/31600804.pdf (last accessed September 15th, 2014)

MONSIVÁIS, Carlos (2010): Apocalipstick. Editorial Debate, Mexico-City.

RABOTNIKOF, Nora (2010): Discutiendo lo público en México. In: ¿Qué tan público es el espacio público en México? Consejo Nacional de la Cultura y las Artes, Fondo de Cultura Económica, Univ. Veracruzana, Mexico-City, pp. 25-57.

RUBAVALVA, Rosa María \& Martha SCHTEINGART (2012): Ciudades Divididas Desigualdad y segregación social en México, El Colegio de México, Mexico-City.

Facebook Site Centro Comercial Angelópolis: https://www.facebook.com/ccangelopolis (last accessed June $25^{\text {th }}$ 2014)

Instituto Nacional de Estadística y Geografía: http://www.inegi.org.mx/ (last accessed September $17^{\text {th }}, 2014$ )

Site La Vista Towers: http://www.lavistatowers.com/towers.html (last accessed September 15th, 2014)

Recebido em: 30/09/2014

Aprovado em: 10/11/2014 